\title{
Women's entrepreneurship at an older age: women linguists' hybrid careers
}

\author{
Tarja Römer-Paakkanen \\ Haaga-Helia University of Applied Sciences, Helsinki, Finland, and \\ Pirjo Takanen-Körperich \\ DACUM Finland, Vantaa, Finland
}

Received 10 July 2020 Revised 10 April 2021 1 November 2021 6 February 2022 Accepted 6 February 2022

\begin{abstract}
Purpose - This study investigates how older women linguists' careers developed and led to self-employment, and this not necessarily in a linear career stage fashion. The focus is on understanding the factors that influence older women to become or continue into an entrepreneurship lifestyle, beyond economic reasons.

Design/methodology/approach - The research questions that guided this research are: (1) How have women linguists' careers developed at older or older old age? and (2) Which factors influenced women linguists' decision to become or continue as self-employed at older or older old age? This study is based on semi-structure interviews and short narratives written by ten informants about their late-career motivations and decisions. To get a holistic view of career development of women linguistics at an older age, the approach adopted in this study is explorative and interpretive, where the theoretical perspective supporting this approach derives mainly from career and wellbeing theories.

Findings - The authors' findings signal that these self-employed older women's careers develop along parallel, explorative or expertise directions. The factors which appear to influence these women's decision to continue their careers as entrepreneurs include economic reasons (having), clearly. They also importantly point to other themes surrounding wellbeing including social relations (loving), self-realization and lifelong learning (being), entrepreneurship as a life style (acting) and meaningful extension of one's career (belonging).

Originality/value - This paper discusses how older women entrepreneurs may experience wellbeing and careers integrated together. It challenges the common notion of "career" as a one-time, linear "choice", and instead shows how older women's entrepreneurship is a complex phenomenon.
\end{abstract}

Keywords Older woman entrepreneur, Self-employment, Age and aging, Wellbeing, Narrative analysis Paper type Research paper

\section{Introduction}

Countries across the Organisation for Economic Co-operation and Development (OECD) are in the midst of a rapid demographic transformation as they are experiencing dramatic growth in their aging population. Due to a decline in fertility and an increase in longevity, older people will outnumber children for the first time in history (e.g. Withnall, 2012, p. 650 sited in Merriam and Kee, 2013; Beard et al., 2012; OECD, 2013; ILO and OECD, 2019.) According to Isele and Rogoff (2014), as the age of the population and the traditional workforce declines and life expectancy rises, entrepreneurs that are older will play an increasingly important role in economic activity. Although this age segment will have a growing impact upon national economic performance, policy frameworks and the business community, there remains a dearth of research in this arena (Isele and Rogoff, 2014).

Isele and Rogoff (2014) state that, although the media has popularized the image of the entrepreneur as a tech-savvy innovator in his/her/their early twenties, recent studies show

(C) Tarja Römer-Paakkanen and Pirjo Takanen-Körperich. Published by Emerald Publishing Limited. This article is published under the Creative Commons Attribution (CC BY 4.0) licence. Anyone may reproduce, distribute, translate and create derivative works of this article (for both commercial and noncommercial purposes), subject to full attribution to the original publication and authors. The full terms of this licence may be seen at http://creativecommons.org/licences/by/4.0/legalcode entrepreneurship at an older age 
QROM

17,2

that the same amount of new businesses were started both by entrepreneurs aged 18-29 years, and those 60 and over. Indeed, the highest rate of business start-up activity is seen in the 55-64 age bracket. Also, Schøtt et al. (2017) confirm that on a global and regional basis, entrepreneurship among older populations is very much a major economic force. In Finland, for example, the number of entrepreneurs has increased only in the 55-74 age bracket (Järnefelt, 2011). Furthermore, in 2017, 13\% of all Finnish entrepreneurs aged 65-74 had been employees but they also continued working as part-time entrepreneurs after their retirement (Sutela and Pärnänen, 2018).

By 2018, in Finland, more than 30\% of entrepreneurs were women; that is, out of 260,000 entrepreneurs approximately 80,000 were women and 180,000 were men (Statistics Finland, 2020). Women seem to gravitate towards entrepreneurship in social, education, health, hotel and restaurant services contexts (Vainio-Korhonen, 2002; Ministry of Employment and Economy (MEE), 2012), and their companies are mainly small (Kyrö et al., 2002). However, while childcare and related family obligations (including supporting the husband's career) influence entrepreneurial behavior among younger women, this may be of limited importance for older women (McKay, 2001). Previous research shows mixed results regarding the effect of pull and push factors on entrepreneurial intentions (Gimmon et al., 2018). Russel (2001) in particular, states that it is important to study the reasons why women establish their own company when they are still salaried employees, and why they decide to leave their paid labor to establish their own company.

The OECD (2017) defines self-employment as those who own and work in their own business, including unincorporated businesses and own-account workers. According to the European Union's (2017) definition, freelancers operate under a range of legal business forms and have several mandators. Solo entrepreneurs work alone without any employees but may have some equity partners. The terms self-employed, freelancer, and solo entrepreneur are treated as synonyms in this work. As such, we discuss how older women experience transitioning from employment to self-employment. Our study challenges the common notion of "career" as a one-time "choice," and as a lifelong channel for one's economic pursuits. Instead, our study demonstrates that career identities, in employment or in self-employment, evolve in an open-ended and flexible fashion in response to the vicissitudes of life (Cedefob, 2008; Vuorinen and Watts, 2010; Nykänen et al., 2012). Specifically, we study the complexity of older women's entrepreneurial aspirations to better understand its nature (e.g. Henry et al., 2016). We studied linguists, who are typically women, and that have had diverse professions. We follow the course of the career development of 10 older women linguists. The target group is a special group of Finnish women who studied applied linguistics during the years 19652001 at the Johannes Gutenberg University Mainz, Germany. They completed a master's degree in translation (Diplomübersetzer), and after graduation they either stayed in Germany, returned to Finland, or moved elsewhere in Europe. Our focus is on the question of how the women linguists' career developed, and led to self-employment at an older age. Career development was examined via our two research questions:

(1) How have women linguists' careers developed at an older or older old age?

(2) Which factors influenced women linguists' decision to continue as self-employed at an older or older old age?

The context of this study draws inspirations from both Finnish (i.e. Northern European) and German cultures, which have different labor distribution traditions. In Germany, generally speaking, men traditionally contribute incomes and women are mainly responsible for childcare, while in Finland combining work and family, and "women's" entrepreneurship has a long tradition (e.g. Welter, 2004). To understand these contextual dimensions, we use an explorative and interpretative approach (Dana and Dana, 2005) to our collected narratives 
from women linguists. Furthermore, age categories in this study are based on Hearn and Parkin's (2021) age categories, that are young adults (18-29 years old), adults of middle years (30-49 years old), older adults (50-64 years old) and older old adults (65-80 years old).

We first consider the literature focused on age and aging, older entrepreneurship, and women and self-employment. We then present our theoretical framework based on pluralistic careers, and then our methodology. Our findings and results are presented, and we discuss our contributions to the questions of why it is important to consider women's entrepreneurship, and our contribution to understanding the factors that motivate older women to continue their hybrid careers.

\section{Literature review}

\section{Age and aging, and wellbeing}

Age is understood mainly as a chronological and universal category, but it has many contexts, including the psychological process of aging as well as the cultural, gendered, generational, career, and human resource management contexts (Aaltio et al., 2017). Retirement systems and practices have changed the way we understand the phenomenon of older age; often the words "retired people" and "old people" are used as synonyms (Kohli, 1991, p. 211 sited in Vaara, 2000, p. 127). According to Baar (1998), there is an interesting paradox developing; that is, that "old people getting younger." People live longer, and older people are healthier than ever, but as they retire earlier than before, they are called "old" younger because they are no longer in the labor market (Baar, 1998, p. 73 sited in Vaara, 2000, p. 127.)

Research (e.g. Merriam and Kee, 2013; Jayo et al., 2010) has demonstrated that the more engaged, active, and healthy older adults are, the less drain they are on community services and resources. At the same time, they contribute to a community's wellbeing through performing many activities. Remaining active and contributing to society has the additional benefit of improving an older person's quality of life and reducing their risk of experiencing poverty. Uotinen et al. (2005) found that the younger the person feels, the better they assess their functional capacity. According to Kooij et al. (2008), individuals with the same chronological age may differ in terms of health, career stage and family status. Furthermore, aging in the literature (e.g. Rowe and Kahn, 1997 sited in Stowe and Cooney, 2015; Rowe, 1997, p. 367 sited in Katz and Calasanti, 2014) seems to be a combination of three components: avoiding disease and disability; high cognitive and physical function; and, engagement with life.

According to Seligman's (2011) definition, wellbeing consists of five aspects: positive emotions, engagement, relationships, meaning and achievement (PERMA). These are, independently, predictors of "flourishing" (Seligman, 2011, 2018; Coffey et al., 2016). According to Allardt (1976) having, loving and being are key components of human wellbeing. Wellbeing can be recognized as one needing to have appropriate housing, sufficient income, and satisfactory health. This is often captured in standard of living indexes, or in Allardt (1976) words, having. One also needs loving relationships and a feeling of belonging to a community, or a sense of community/loving. Furthermore, one should be able to influence one's life and to make a difference in relationships or in the surrounding community, where this is considered self-realization/being. In practice, these three dimensions are intertwined (Allardt, 1976). Raivio and Karjalainen (2013) presented that an individual's wellbeing can also be examined by balanced participation theory. People can feel participation when they have enough tangible resources (having), when they can actively influence the decisionmaking processes concerning their own life (acting), and when they have meaningful and important social relations with other people, which enables them active participation to society (belonging). The lack, or decrease, of participation can increase an individual's risk for social exclusion.

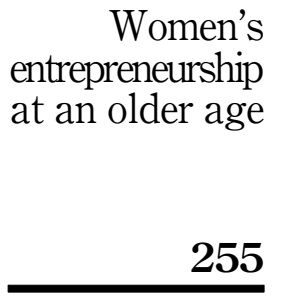


QROM

17,2

\section{Older entrepreneurship: productive aging}

Generally speaking, entrepreneurship can be divided into opportunity driven (pull) entrepreneurship and necessity driven (push) entrepreneurship (e.g. Reynolds et al., 2002; van der Zwan et al., 2016; Jamil et al., 2014). As examples of this pull- and push-type of entrepreneurship with respect to older entrepreneurs, Weber and Schaper (2003) propose that a factor having an impact upon grey entrepreneurial tendencies is the broader social context within which the individual operates. Some societies value aging and believe that older individuals have greater wisdom and experience; others treat older adults as largely incapable and as dependent with little left to contribute. If a society is culturally supportive of independent entrepreneurial endeavor as part of what is termed "productive aging", then more individuals are likely to start or run their own business. According to Martin and Omrani (2019), motivating older adults, having the skills needed, risk tolerance, and some other variables related to the environment, influence these adults' decisions to engage in entrepreneurial behavior.

Kyrö et al. (2012) suggested three groups of older entrepreneurs: (1) those who worked as employees become entrepreneurs as they retire; (2) those who worked as employees and retire but later start their own business and become an entrepreneur; and (3) those who were entrepreneurs and continue their entrepreneurship after retirement. According to the European Commission (Halabisky, 2012), there is notable variation in the levels of entrepreneurship activity within the older age group between 36 countries, including the 28 EU Member States, Turkey, three EFTA countries, the US, Japan, China, and South Korea. There is little difference in the entrepreneurial activity rates (thinking about or early-stage entrepreneurial activity) between prime working-age and older people in Iceland, the United States, Romania and Slovakia, while older people in countries such as Austria, France, Belgium and China are less likely to follow an entrepreneurial career. According to Pilkova et al. (2014), there is a growing tendency of grey entrepreneurship in some highly developed European countries (i.e. Sweden and Finland) with a long tradition of an open market economy and with high living standards.

In Finland, the retirement age is 63 years, which is reflected in the age of the informants in this study, and the age when pension insurance obligation ends is 68 years. Employees and the self-employed can claim an old-age pension thereafter, and start or continue their selfemployment (Finnish Centre for Pensions, 2021). According to Ilmarinen (2006), approximately one-third of entrepreneurs calculate that they will work until the age of 63, and one-sixth plan to work until 65. Many entrepreneurs also tend to work after retirement, highlighting an important difference with respect to having a long career between entrepreneurs and other salaried workers. According to Singh and DeNoble (2003), those retirees rejoining the labor market as salaried employees are typically less wealthy, healthy, attached to work, or want to take advantage of a supportive economic climate. Those retirees who become self-employed, however, are likely to be wealthier, have networks, and have an entrepreneurial tendency. According to Kauko-Valli (2008), entrepreneurship enables people to complement their livelihoods if their pension is small. It also influences other elements of wellbeing. Tervo and Haapanen (2017) presented that for many older individuals, entrepreneurship is seen as a career option or as a form of partial retirement as it allows them the freedom to adjust their working hours. Kautonen et al. (2014) found that entrepreneurial activity increases almost linearly with age for individuals who prefer to only employ themselves, whereas it increases up to a critical threshold age (late 40s) and decreases thereafter for those aspiring to hire workers.

In Finland, individuals with prior entrepreneurial experience have established almost half of the grey entrepreneurs' start-ups (Kautonen, 2008). In their study, Singh and DeNoble (2003) sub-divided early retiree entrepreneurs into three types: rational, constrained, and reluctant. Rational entrepreneurs cover individuals who decide to become self-employed as a 
rational choice. Constrained entrepreneurs have relatively high entrepreneurial tendencies, but they have been unable to act on such tendencies earlier in their careers due to established or perceived constraints. Reluctant entrepreneurs do not choose to become entrepreneurs as they would prefer to return to their previous positions as salaried employees although they may be relatively successful (e.g. Singh and DeNoble, 2003; Yaniv and Brock, 2012). The literature maintains that older people are generally more capable of starting and running businesses (Lechner and Dowling, 2003; Kibler et al., 2012; Singh and DeNoble, 2003; Weber and Schaper, 2003; Kautonen, 2013), and their companies are also more successful (Hart, 2007 sited in Tomlinson and Colgan, 2014; Khan, 2013).

\section{Women and self-employment}

The literature (e.g. Kovalainen, 1992, 1999; Reijonen and Komppula, 2004; Dangel, 2006; Robb and Coleman, 2010) shows that women as new entrepreneurs has been an important feature of European entrepreneurship's growth in the last 30-40 years. According to OECD (2017), in OECD economies, $10 \%$ of employed women and $17 \%$ of employed men are self-employed. During the past 10 years, the gap between men's and women's self-employment rates has narrowed in almost every country. In the majority of countries, self-employed women mostly work alone, and men are two and a half times more likely to employ others than self-employed women (OECD, 2017). According to Suomalainen et al. (2015), in Finland, an established business owner is about two times more likely to be a man $(14.2 \%)$ than a woman $(6.1 \%)$. The share of such ownership among women in Finland is, however, higher than the average of EU countries.

Orhan and Scott (2001) present that women become entrepreneurs via different routes: dynastic compliance, no other choice, entrepreneurship by chance, natural succession, forced entrepreneurship, informed entrepreneur, and pure entrepreneur. According to Welsh and Dragusin (2006), women are motivated by the need for independence and achievement arising from job frustration. Both Welsh and Dragusin (2006), and Tomlinson and Colgan (2014) report that women mention flexibility and family related reasons for becoming self-employed, whereas men's reasons show little association with their parental status. Pääkkönen and Hanif (2011) state that flexibility is more important for women as they are generally mostly responsible for household work.

In Schøtt et al.'s (2017) study, entrepreneurial intentions are lowest among older (aged 50-64) women compared to younger (aged 18-29), middle years (aged 30-49), and older old (aged 65-80) women, with fewer than seven women wanting to start a business for every 10 men in this older age group. Older old individuals (aged 65-80) report the widest gender gap in terms of early-stage entrepreneurial activity, with only six women engaged in start-up activity for every 10 men. Older men (aged 65-80) entrepreneurs are twice as likely to be pursuing an opportunity entrepreneurship rather than being necessity driven (Schøtt et al., 2017).

Older women (aged 50-64) are only marginally more likely to be motivated by opportunity entrepreneurship rather than being forced into necessity entrepreneurship due in part to a lack of other options for sustainable livelihoods (Schøtt et al., 2017). Moore (2020) states that for women in later life, venture creation may be a rewarding alternative to retirement. It provides them a means to generate additional income to supplement inadequate pensions caused by career breaks or divorce, or to fulfill a long-held ambition. According to Tomlinson and Colgan (2014), there are four themes that can explain and justify the pursuit of older women's self-employment. The first is continuity which means they have had an ongoing interest in self-employment for a longer time. The second is validation which explains that their experiences both within and outside their work provide evidence of their capacity to be self-employed. The third is change that expresses that this life stage gives them an opportunity to change their lives by becoming self-employed. 
QROM

17,2

258

Finally, the fourth is agency which means that their stories can be interpreted as the selfrepresentation of an active agent.

Many researchers (e.g. Pöllänen, 2002; Vardhan et al., 2020) point out that there are no differences between entrepreneurial men and women in personality dimensions such as achievement, motivation, independence, leadership, and risk-taking propensity. Men generally see entrepreneurship as a business decision, whereas many women view it as a life choice - a way of integrating family and career needs. Buttner (1993) referring to Noble (1986), wrote: "For men, being an entrepreneur is a business strategy. For women, it's a life strategy". Mainieiro and Sullivan (2005) found differences between men and women, where women's career decisions were normally part of a larger and intricate web of interconnected issues, people, and aspects that had to come together in a delicately balanced package. Women make decisions about their career options after considering the impact their decisions will have on others. Díaz-García (2018) sited Thébaud (2015), when stating that the presence of institutional arrangements to mitigate work-family conflict (paid leave, subsidized childcare, and part-time employment opportunities) make women less likely to opt for entrepreneurship. Also, Ahl and Nelson (2015) adduce that one would think that the welfare state would entice women toward self-employment, but research shows the opposite.

\section{Theoretical framework: pluralistic careers}

The early, more traditional career theories assumed career stages that were linear and stable, with steady progression through the hierarchy. For instance, Hall and Goodale (1986) indicated the stages in career development as a line of different periods of life, that are exploration, trial, establishment, maintenance (growth, stagnation), and decline. Super (1957, 1990), on the other hand, defined career development more as a dynamic, longitudinal, and developmental process that essentially consists of developing and implementing the selfconcept. Sullivan and Baruch (2009) present that an emergent concept of hybrid careers, that contain aspects of both the traditional and protean or boundaryless career concepts, is also used but it is not specifically associated with any scholar. According to Mainieiro and Sullivan (2005), women shift their career's pattern by rotating different aspects of their lives to arrange their roles and relationships in new ways. Richardson (1996) described women's careers as "snake-like”, whereas men's careers are more "ladder-like." As stated by several researchers (e.g. Gersick and Kram, 2002; O’Neil et al., 2008; Wang and Shi, 2014), women must divide their priorities between nurturing relationships and following more individualistic ambitions, but there may be some other core values that influence their career decisions (Hall, 2004).

Brousseau et al.'s (1996) fluid and dynamic pluralistic career model with its underlying four career concepts, that is, linear career, expert career, spiral career, and transitory career, is at the center of this study. The idea is that discrete elements of fluid career patterns, or career concepts, can intermingle and that they "differ in terms of direction and frequency of movement within and across different kinds of work over time" (Brousseau et al., 1996, p. 56). Such an intermingling gives rise to hybrid concepts with respect to careers. Adding to this pluralistic model, we looked to Takanen-Körperich's (2008) work on the diverse career development model. We added two more alternative career concepts to Brousseau et al.'s (1996) four career concepts; that is, the parallel career and the explorative career. Notably, in a parallel career, a person can simultaneously be active in several fields such as salaried work along with self-employment. In the explorative career, a person can unintentionally find a different kind of working life and environment than the one initially proposed by their educational studies. Nevertheless, they can benefit their education and expertise in those different environments. Key features of these six concepts are summarized in Table 1. 


\section{Methodology}

This study concentrates on women of an older and older old age (Hearn and Parkin, 2021), that is on, those years following the informants' retirement. The focus is on studying how women linguists' careers developed at an older or older old age, and on the factors which influenced the women linguists' decision to develop their careers beyond salaried employment. The approach adopted in this study is explorative and interpretive (Dana and Dana, 2005), supported by the theoretical framework on pluralistic careers. Across the various phases of this study, we relied on our own entrepreneurship experiences such as in planning interviews, in discussions with the entrepreneurs, in interpreting the narratives, and in discussing the findings. Therefore, there is an element of self-reflexivity across our methodological approach.

\section{Data collection}

The data were collected via semi-structured interviews, and by written narratives produced by the informants about their late career and on their entrepreneurship experiences at an older age. According to McAlpine (2016), narratives are one of many interpretive approaches that has been used in sociology and in organizational, gender, and education studies. Narratives involve telling stories by recounting how individuals make sense of events and actions in their lives - with themselves as the agents of their lives.

In the spring of 2017, a total of 20 women who were self-employed as linguists were interviewed and invited to write a short narrative by e-mail about their life. The following questions guided these interviews and their narratives: What is their family situation? If they are still working, what are they doing? If they are working, what are the reasons for continuing to work? If they are entrepreneurs, what are the reasons they have chosen to continue as an entrepreneur? What is the way they were working/what kind of business do they have? Who are their clients/students, etc.? How long do they intend to continue as an entrepreneur?

Three of these potential informants did not reply to our request, whereas seven of the 20 had left working life, and 10 informants were retired or were going to retire soon but were selfemployed. As the target group consists of linguistic experts, it was not difficult for these 10 informants to write narratives about their experiences, and hence we had 10 focused, welldeveloped narratives to study.

\section{Analyzing and interpreting the narratives}

In this study, by using both the literature and empirical data abductively, we set out to identify the late career development of the informants both in and outside of Finland.

\begin{tabular}{lllllll}
\hline & & \multicolumn{5}{c}{ Key features and motives } \\
& Linear & Expert & Spiral & Transitory & Parallel & Explorative \\
\hline $\begin{array}{l}\text { Direction of } \\
\text { movement }\end{array}$ & Upward & $\begin{array}{l}\text { Little } \\
\text { movement }\end{array}$ & Lateral & Lateral & $\begin{array}{l}\text { Forward } \\
\text { lots of } \\
\text { movement }\end{array}$ & Forward \\
$\begin{array}{l}\text { Duration of } \\
\text { stay in one } \\
\text { field }\end{array}$ & Variable & Life & $7-10$ years & $3-5$ years & Variable & Several years \\
$\begin{array}{l}\text { Key motives } \\
\text { Power }\end{array}$ & $\begin{array}{l}\text { Expertise } \\
\text { achievement }\end{array}$ & $\begin{array}{l}\text { Personal } \\
\text { growth } \\
\text { creativity }\end{array}$ & $\begin{array}{l}\text { Variety } \\
\text { independence }\end{array}$ & $\begin{array}{l}\text { Personal } \\
\text { growth } \\
\text { variety }\end{array}$ & Expertise \\
& independence
\end{tabular}

Women's entrepreneurship at an older age 
QROM

17,2
According to Fletcher (2007), narrative analysis helps researchers to move beyond the "what" and the "how" of entrepreneurship while being able to answer theoretically "why" such processes migrate and stretch across different cultures and contexts. The gathering of narrative data, data processing, and analyzing are tightly intermingled. In narrative-based research, the data that is to be analyzed by the researchers represent the narrators' efforts to describe and interpret themselves using their own experiences (White, 1989 sited in Mishler, 1990, p. 424.)

The focus is on understanding the factors that influence the informants' decision to continue as self-employed in their older age. When writing the narratives, the informants gave meaning to their experiences and actions, simultaneously narrating themselves and their identities. The narratives provide a means for approaching the life history of the informants. Thus, the emphasis is on the informants' own perspectives and perceptions. Informants not only divulged information about their lives, but they also had an opinion on what happened and on what they experienced, and also on what they may desire from their future. Each one evaluated her life and gave it meaning, retrospectively thinking about why entrepreneurship is still in their lives.

The narratives were analyzed by building explanations around each informant's case. Following this step, theoretical positions were revised and the evidence was examined once again by using thematic analysis (McAlpine, 2016). Then the narratives were analyzed from a new perspective, in an iterative mode, within the context of five essential life and career elements: (1) family and life situation; (2) working history; (3) career concept; (4) ways of entrepreneurship; and (5) reasons for self-employment. A chart of the major life and career development stages of each informant was then outlined according to this narrative analysis approach. We now turn to the findings of this study.

\section{Findings}

Table 2 summarizes some of the key elements surrounding our 10 informants.

All 10 informants had some experience of entrepreneurship, either through selfemployment or freelancing, during their professional path before retiring, as summarized in column six of Table 2. Two of the informants worked as salaried employees, and already combined employment and self-employment or freelancing before their retirement. After retiring, these two informants continued working as self-employed or freelancer linguists. Eight of the informants were entrepreneurs, self-employed or freelancers, before retiring and they continued this type of career after retiring. This result is in line with the literature, where according to solo entrepreneur inquiry, such a hybrid model of combining retirement and entrepreneurship has increased in Finland, as 26\% $(n=1874)$ of the respondents stated that besides their entrepreneurship they had a pension based on their paid employment (Suomen yrittäjät, 2019).

All our informants had the same educational background but they had different kinds of career paths. All informants in an expert career (3) were committed to their initial education field, and were freelancer translators, teachers and consultants, and they continued work as freelancers after their retirement. Those in parallel careers (5) were simultaneously in salaried work in an office or in their own businesses, and they also worked as freelancer translators and teachers. Those who had explorative careers (3) had found different kinds of jobs and businesses where they could utilize their competencies and background in different environments. They combined freelance translating and teaching work for instance with tourism and travel consulting or with tax counselling. None of our informants had a linear, traditional career path. Generally, their careers were hybrid as they all combined different ways of working and implemented their initial education differently. They all developed their competencies continuously, and made their career decisions on their family terms. 


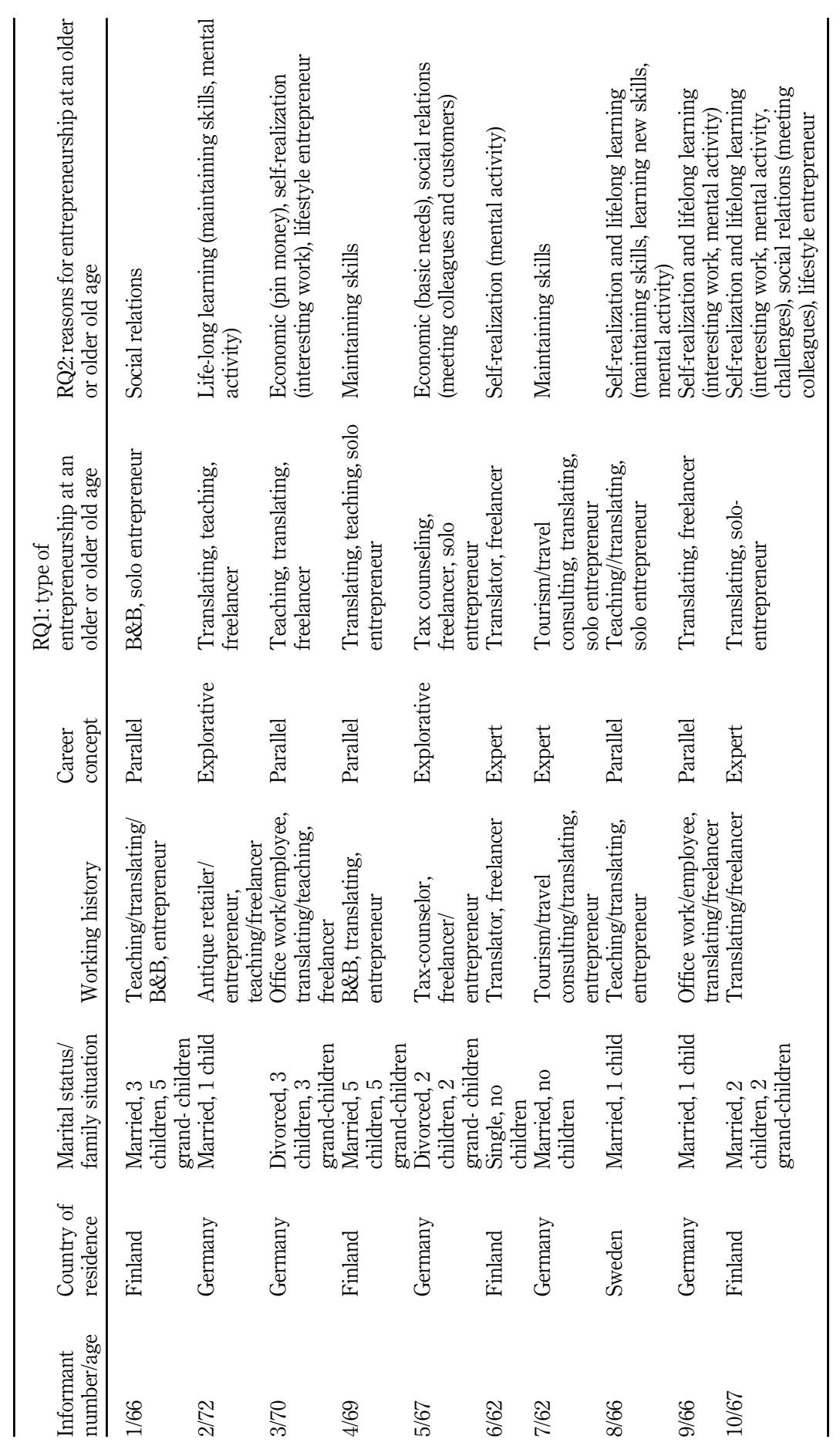

Women's entrepreneurship at an older age

261

Table 2.

Key elements of study participants 
QROM

17,2

262

According to Seymour (2002), older entrepreneurs' reasons for starting businesses are often unique. Some say they are restless, others have the desire to pass something on to their descendants, and still others want to pursue their dreams or ideas after long careers as employees. In our study, with respect to the factors that influenced these informants' decisions to continue their careers as self-employed in older age, all the informants had retired from their paid work or from their previous entrepreneurial activities, but they still wanted to continue as entrepreneurs. The reasons they shared with us, as summarized in the last column of Table 2, can be divided into the following groups: economic reasons; social reasons; self-realization and lifelong learning; and, entrepreneurship as a lifestyle.

\section{Economic reasons}

Singh and DeNoble (2003), referring to several prior research initiatives, state that the lack of wealth due to no inheritance or pension benefits decreases the appeal of leisure. According to Way (2015), this in turn decreases the minimum wage that the worker requires in order to participate in the labor market (i.e. reservation wage) and encourages them to return to work. Schøtt et al. (2017) reported that compared to other age groups, older women show the highest relative prevalence of necessity motivation for entrepreneurship due to a lack of other options for a sustainable livelihood.

Maintaining entrepreneurship is not only an opportunity, but it can be a reluctant or necessity-driven action. For instance, in Germany, the school system requires that mothers stay at home as the children come home for lunch. According to Tuomi-Nikula (1989), Finnish women often remain at home when living in Germany. As such, after divorce, those Finnish women have such a small pension that there is a clear economic need to continue to work. On the other hand, if the divorced informant lives in Finland, she usually has worked full-time; however, due to low wages, her pension is not enough to sustain her basic needs either. Informant 5, for example, stated quite clearly to us that "My pension does not cover even my basic expenses [...] I am obliged to work as long as I have customers." Some of our informants, on the other hand, could be categorized as rational entrepreneurs (Singh and DeNoble, 2003) whereby they want to earn some pin money, for example, for traveling: "Extra money from teaching is always welcome because with that money I can visit Finland" (Informant 3).

\section{Social relations}

According to Escuder-Mollon (2012), people need to share activities with other people. At any age, isolation can cause undesirable negative impacts including irrational thoughts, disturbed behavior, etc. In older age, there are any number of contributors that can lead to isolation such as the death of relatives, children becoming independent, friends moving away, etc., that are not negligible. According to Buttner (1993), women and men may have different priorities in establishing networking relationships. Notably, men's motives are often more instrumental (i.e. seeking personal gain) while women have more affective considerations in social relationships.

Some of our informants expressed that they do not work for economic reasons but that they want to meet other people and to maintain their social relationships. In our research, these informants need the social connections which working life offers: "In seminars and conferences, I meet colleagues with whom I am in contact also by email, etc. In recent years, the live-seminars were replaced by webinars, which means that I do not meet my colleagues face-to-face anymore" (Informant 10).

\section{Self-realization and lifelong learning}

Mainieiro and Sullivan (2005) suggest that women in their late career may ask the following question of themselves: "Is that all there is?" Women appear to have a desire for authenticity, 
of being true to themselves, and to making decisions that suit them. This includes an interest in facing challenges, but on their own terms, and making decisions in an authentic, meaningful way. Our informants clearly stated that they work to stay up to date with their knowledge, and to succeed in their future life. They want to utilize their spare time, and they are curious to learn and to develop themselves. Perhaps this notion of authenticity is best summarized by Informant 4: "Today I can choose my work, and I am very happy about this."

Terjesen (2005) found that senior women managers leaving corporate organizations want to benefit from their embedded career capital, such as human capital (knowing how) and social capital (knowing whom). These women managers have accumulated this capital from their personal experiences, knowledge, skills, relationships, and networks, when founding and growing their own businesses. Our informants also wanted to leverage their prior experiences, to use their competencies and to further develop themselves: "I had the pleasure to organize a seminar [...]I really learnt a lot from organizing and supervising how to handle the tasks which came up" (Informant 10); "Work is interesting, and it challenges me continuously to check and update my skills" (Informant 3).

With respect to life-long learning, Escuder-Mollon et al. (2014) state that learning in later life is becoming more common. Job-related needs or labor market qualification requirements are being replaced by a need to fulfill more personal aims such as curiosity, understanding the environment, feeling more integrated, pleasure, or keeping active. These personal aims can be seen from a quality-of-life perspective, where education increases wellbeing and understanding of self and society. This search for and accomplishment of personal aims help older learners to feel that they are participating in and forming part of society (EscuderMollon et al., 2014). According to the Commission of the European Communities (2005), entrepreneurship is one of the key competences of lifelong learning that individuals need for personal fulfillment and development, active citizenship, social inclusion, and employment. These experiences were mirrored extensively in our informants narratives. For example: "Working and learning keep me alert and my brain active" (Informant 8); and, "Work gives me always something new" (Informant 10).

\section{Entrepreneurship as a lifestyle}

Entrepreneurship and work are important parts of the informants' identity and lifestyle. Some simply stated that they like their work, and want to continue as long as possible as entrepreneurship is part of their lifestyle: "I keep teaching as long as my feet can hold me up and I am able to talk" (Informant 3); "I like my job. It gives me a lot: Thinking, activity, challenges [. . . ] I have always been either a freelancer or an entrepreneur. I cannot imagine the day when I will not work anymore!" (Informant 10).

Some of the informants called themselves "lifestyle entrepreneurs." At present, there is very little research and no clear definition of the phenomenon of this lifestyle entrepreneur. Masurel and Snellenberg (2017) do summarize that lifestyle entrepreneurs strive for a balance between their personal life, on the one hand, and their business life, on the other, by putting an emphasis on their own lives. Gibb (2002) also does state that when individuals move from employment or a position of relative security into entrepreneurship, a variety of changes can take place in their "life world": "There is greater autonomy to make things happen, but a wide range of tasks have to be undertaken. Interdependence of a diverse group of people has to be managed, and networks of trust have to be built as a basis for this" (Gibb, 2002, p. 137). Deacon and Firebaugh (1988) and Morris (1998) describe entrepreneurship as a sustainable, systemic process, varying in frequency and intensity during an individual's life span. Finally, Marcketti et al. (2006) emphasize that entrepreneurship has an impact on the entire sphere of life. There also seems to be a relationship between lifestyle entrepreneurship, and life quality for families and communities. Such a systems approach posits that the successful launch and operation of a business will lead to an improvement in an entrepreneurs' overall quality of life.

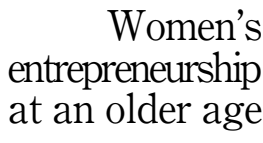

263 
$\mathrm{QROM}$

17,2

\section{4}

Figure 1.

Factors that influence women linguistics' decision to continue self-employment at an older or older old age
Summary of findings

Our findings support the results of previous research on older entrepreneurs (e.g. Singh and DeNoble, 2003; Kautonen et al., 2014; Kautonen et al., 2015). Notably, that there is a combination of social, financial, and personal reasons for retirees' decision to become selfemployed or entrepreneurs. Even if and when there are different motives and targets for older entrepreneurship, there are also similarities that exist such as commitment to work, and the meaningful extension of one's career. Older entrepreneurship can arise from a former business, personal competencies or hobbies. According to Kyrö et al. (2012), motivation to make such a career move can also come from the desire for self-realization in, for example, a non-profit-making business or in investing in new businesses. Schøtt et al. (2017) state that older people often possess an advantage over the younger population as they have more developed networks, are in a stronger financial position, can assist in mobilizing resources, can create legitimacy during a start-up and growth, and have acquired social capital during their career employment.

Giving a finer grain to our understanding of older entrepreneurs and drawing inspiration from Allardt (1976) and Raivio and Karjalainen (2013) themes surrounding wellbeing and participation theory, we are able to organize the reasons and motivations behind why our informants continued as self-employed or entrepreneurs. Their economic situation (having), where their pension is poor, or they need extra income for traveling or for something that brings comfort such as maintaining the house they live in, etc., provides a view into older women linguists' wellbeing. Social relations (loving) is also important and is reflected in meeting people and feeling that one is part of the community. Self-realization (being), where one is feeling active and capable, and is driving one's curiosity and need for lifelong learning is also present in our informants' narratives. Also, entrepreneurship as a lifestyle (acting) underscores that entrepreneurship is part of our informants' identities, and that this lifestyle interacts with personal and family issues in varying life stages. These themes and how they may lead to productive aging are summarized in Figure 1.

Furthermore, with respect to older women entrepreneurs having meaningful and important social relations with other people, which according to Raivio and Karjalainen (2013) enables active participation to society (belonging), we turn to the literature again to provide some insight into our findings. Notably,Schøtt et al. (2017) state that older people want to keep active minds. They also often possess advantages over the younger population as they have more developed networks, can assist in mobilizing resources, can create legitimacy during a start-up and growth, and have acquired social capital during their career

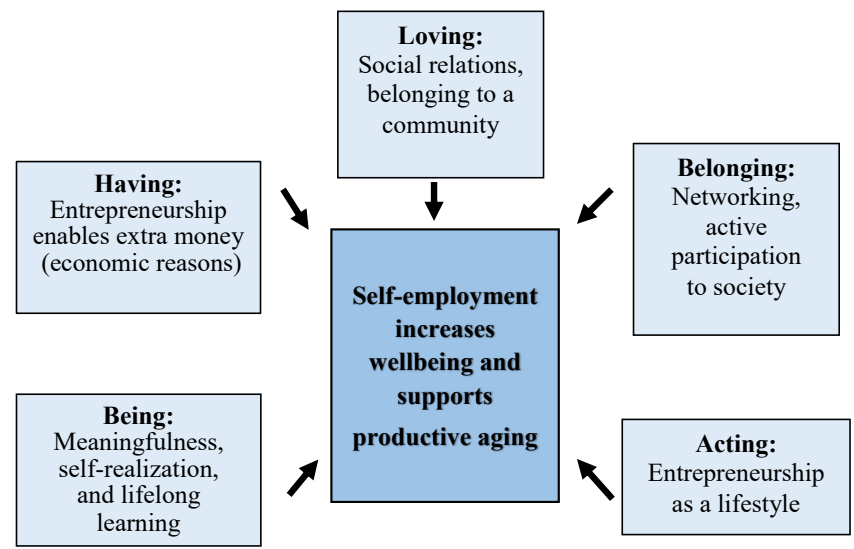


employment. According to Kyrö et al. (2012), even if older entrepreneurs have different motives, they also have important similarities like their commitment to work and to the meaningful extension of one's career. These elements were found in our informants' interviews and in their narratives, thereby bringing belonging as an additional theme.

\section{Discussion and conclusion}

Aaltio and Wang (2016) set down three questions in their literature-based study analyzing research on women's entrepreneurship: (1) Why is women's entrepreneurship a focus of entrepreneurship research? (2) How does current research contribute to women's entrepreneurship both from conceptual and practical points of view? (3) What are the future research needs for women's entrepreneurship as indicated by the findings? These questions drove our inquiry in this study, where we explored the "how" of women linguists' careers developing at an older or older old age, and which factors influenced these women linguists' decision to continue as self-employed.

Drawing inspiration from Aaltio and Wang's (2016) first and second question, as little as is known about the reasons for why older people become self-employed (e.g. Weber and Schaber, 2003; Heimonen, 2013; Luck et al., 2014; Fachinger, 2019), we do believe we need to widen the understanding of older entrepreneurship and particularly for the case of older women's entrepreneurship. Clearly, as Weber and Schaber (2003) state, entrepreneurship efforts of older people will have a growing impact on national economic performance, policy frameworks, academia and the business community. However, as we found in our study, economic reasons are not the only drivers into older entrepreneurship. Social relations (loving), self-realization and lifelong learning (being), along with lifestyle entrepreneurship (acting) are also themes that drive our growing understanding of older women entrepreneurs. Furthermore, our informants expressed important similarities, like their commitment to work and to the meaningful extension of one's career, surfacing the theme of belonging.

Interestingly, our informants continued to work as self-employed individuals in the same field as they worked in for their last salaried job before retirement. This underscores the parallel career model in five (5) out of 10 informants' career paths, as opposed to careers that follow a linear trajectory. None of our 10 older women entrepreneurs followed this linear trajectory. Our informants actively combined entrepreneurship and retirement, along with some other activities in various fields of their life. Late career for these informants is influenced partly by the knowledge and skills resulting from their lifelong learning processes, along with their work experiences and, in some cases, by the constraints of family needs. Some of our informants (3) regarded themselves as experts in their professional fields, mirroring Brousseau et al.'s (1996) expert career concept, where their motivation is one centered on security along with being recognized as an expert. Finally, two (2) of our informants followed an explorative career concept which gives them financial independence and supports their mental activity and social relations.

Still working within Aaltio and Wang's (2016) second question, from a practical point of view, we are contributing to a greater understanding with respect to the factors that can motivate women to continue as entrepreneurs after their retirement. Again, our results show that economic reasons are not the main motivators, at least for these older women linguists. Some of the main drivers into entrepreneurship include a person's core values, meaningfulness and self-realization, desire for lifelong learning, and the building or continuing of social relations. In addition, entrepreneurship is an important part of these informants' identities and their chosen entrepreneur lifestyle. Our results mirror Nivalainen and Tenhunen's (2019) research, as their respondents also enjoyed continuing working as entrepreneurs at their older or older old age. 
QROM

17,2

266

When reflecting on Aaltio and Wang (2016) third question, future directions point to research into older women's entrepreneurship in other European countries and in other fields beyond being a linguist. As in Maritz's (2015) study, the limitations of our study are linked to the lack of substantial empirical studies in the older entrepreneurship domain and, in particular, to the lack of studies on older women's entrepreneurship. Due to the specific target group of the study, the results cannot be generalized to the population of older women entrepreneurs. We found that semi-structured interviews and narratives proved to be a suitable method for collecting data as it also gives the informants an interesting way to contribute to the research, and to think about what they want from the rest of their lives with a wellbeing mindset, and their careers: what are their motivations, desires, and volitions? Furthermore, our familiarity with the entrepreneurial field and with the lifestyle helped us narrow our focus on specific themes in the interpretation work of the narratives. However, this familiarity also brought its own difficulties, particularly when developing new questions to pursue during the interview part of the collection of data, and then finding and applying new perspectives for data interpretation. Future collaborative work could therefore include colleagues that are less familiar with the entrepreneurial lifestyle, which could then lead to new perspectives being developed.

In conclusion, age and aging as such were not the core concepts of this research. Age and aging did however provide us a field of inquiry that is rarely considered in academic and practitioner work, and provided an interesting career concept perspective along with a wellbeing life course in which to interpret our collected data. The importance of our findings and accompanying analysis, which mirror Merriam and Kee's (2013) work, point to the importance of being more socially active, creating awareness of self-realization and lifelong learning along with the benefits of the entrepreneurship lifestyle beyond economic gains. All of this can lead to older women's independence across the life course, and can contribute to their wellbeing. At the same time, older women entrepreneurs that are active in the community can contribute to overall community wellbeing through their accumulated life experience, expertise, and engagement in service.

\section{References}

Aaltio, I. and Wang, Q. (2016), "Making sense of women entrepreneurship research: a qualitative metaanalytical review", ICSB 2016 World Conference, Proceedings, International Council for Small Business, pp. 1-19.

Aaltio, I., Mills, A.J. and Halms Mills, J. (2017), "Introduction: why to study ageing in organisations?", Palgrave Macmillan, Springer Nature, Cham, available at: https://1lib.sk/book/3376004/d5af67 (accessed 25 February 2022).

Ahl, H. and Nelson, T. (2015), "How policy positions women entrepreneurs: a comparative analysis of state discourse in Sweden and the United States", Journal of Business Venturing, Vol. 30 No. 2, pp. 273-291, doi: 10.1016/j.jbusvent.2014.08.002.

Allardt, E. (1976), Hyvinvoinnin Ulottuvuuksia [Dimensions of Wellbeing], WSOY, Juva.

Baar, J. (1998), “Aika, gerontologia ja vanheneminen”, Gerontologia, Vol. 12 No. 2, pp. 72-81.

Beard, J.R., Biggs, S., Bloom, D.E., Fried, L.P., Hogan, P., Kalache, A. and Olshansky, S.J. (2012), "Introduction, global population ageing: peril or promise?", World Economic Forum. pp. 4-13, available at: https:/demographic-challenge.com/files/downloads/6c59e8722eec82f7ffa0f1158d0f 4e59/ageingbook_010612.pdf (accessed 30 June 2019).

Brousseau, K.R., Driver, M.J., Eneroth, K. and Larsson, R. (1996), "Career pandemonium: realigning organizations and individuals", Academy of Management Executive, Vol. 10 No. 4, pp. 52-66.

Buttner, E.H. (1993), "Female entrepreneurs: how far have they come?", Business Horizons, Vol. 36 No. 2, pp. 59-65. 
Cedefop (2008), "Establishing and developing national lifelong guidance policy forums. A manual for policy-makers and stakeholders", Cedefop Panorama Series; 153. Office for Official, Publications of the European Communities, Luxemburgh, available at: http://www.cedefop. europa.eu/EN/Files/5188_en.pdf (accessed 31 October 2021).

Coffey, J.K., Wray-Lake, L., Mashek, D. and Branand, B. (2016), "A multi-study examination of wellbeing theory in college and community samples", Journal of Happiness Studies, Vol. 17, pp. 187-211, doi: 10.1007/s10902-014-9590-8 (accessed 28 December 2019).

Commission of the European Communities (2005), "Proposal for a recommendation of the European parliament and of the council on key competences for lifelong learning", available at: http://ec. europa.eu/education/policies/2010/doc/keyrec_en.pdf (accessed 21 May 2019).

Dana, L.P. and Dana, T.E. (2005), "Expanding the scope of methodologies used in entrepreneurship research", International Journal of Entrepreneurship and Small Business, Vol. 2 No. 1, pp. 79-88.

Dangel, C. (2006), "Gender aspects in setting up business and self-employment - a comparison between Germany and selected European countries", in Römer-Paakkanen, T. and TakanenKörperich, P. (Eds), Family Business in Transition - Need for New Entrepreneurs and Entrepreneurship Education Workshop Proceedings, F. M. (1988), Haaga Instituutin ammattikorkeakoulu, HAAGA Raportteja 5, pp. 25-30.

Deacon, R.E. and Firebaugh, F.M. (1988), Family Resource Management: Principles and Applications, 2nd ed., Allyn \& Bacon, Boston.

Díaz-García, C. (2018), “Gender and entrepreneurship at the crossroads: where do you want to go?”, in Blackburn, R., De Clercq, D. and Heinonen, J. (Eds), The SAGE Handbook of Small Business and Entrepreneurship, Sage, London.

Escuder-Mollon, P. (2012), "Modelling the impact of lifelong learning on senior citizens' quality of life", Procedia - Social and Behavioral Sciences, Vol. 46, pp. 2339-2346.

Escuder-Mollon, P., Esteller-Curto, R., Ochoa, L. and Bardus, M. (2014), 'Impact on senior learners' quality of life through lifelong learning", Procedia - Social and Behavioral Sciences, Vol. 131, pp. 510-516, doi: 10.1016/j.sbspro.2014.04.157 (accessed 30 June 2019).

Fachinger, U. (2019), "Senior entrepreneurship. Self-employment by older people - an uncharted territory. Conference paper", Zagreb International Review of Economics and Business, Vol. 22 No. Special Conference Issue, pp. 95-106, doi: 10.2478/zireb-2019-0007.

Finnish Centre for Pensions (2021), available at: https://www.tyoelake.fi/en/different-pensions/old-agepension-birth-year-determines-retirement-age/\#title (accessed 28 October 2021).

Fletcher, D. (2007), “Toy Story': the narrative world of entrepreneurship and the creation of interpretive communities", Journal of Business Venturing, Vol. 22 No. 2007, pp. 649-672, doi: 10.1016/j.jbusvent.2006.10.001.

Gersick, C.J.G. and Kram, K.E. (2002), "High-achieving women at midlife. An exploratory study", Journal of Management Inquiry, Vol. 11 No. 2, pp. 104-127.

Gibb, A. (2002), "Creating conducive environments for learning and entrepreneurship. Living with, dealing with, creating and enjoying uncertainty and complexity", Industry and Higher Education, Vol. 16 No. 3, pp. 135-147.

Gimmon, E., Yitshaki, R. and Hantman, S. (2018), 'Entrepreneurship in the third age: retirees' motivation and intentions", International Journal of Entrepreneurship and Small Business, Vol. 34 No. 3, pp. 267-288.

Halabisky, D. (2012), Policy Brief on Senior Entrepreneurship. Entrepreneurial Activities in Europe, Publications Office of the European Union, Luxembourg, available at: http://hdl.voced.edu.au/ 10707/293809 (accessed 28 June 2019).

Hall, D.T. (2004), “The protean career: a quarter-century journey”, Journal of Vocational Behavior, Vol. 65, pp. 1-13.

Hall, D.T. and Goodale, J.G. (1986), Human Resource Management. Strategy, Design and Implementation, Scott, Foresma and Company, London. 
QROM

17,2

268

Hart, M. (2007), Senior Start-Ups Study, Yell.com/Small Business Centre, University of Kingston, London.

Hearn, J. and Parkin, W. (2021), Age at Work: Ambiguous Boundaries of Organizations, Organizing and Ageing, Sage, London.

Heimonen, T. (2013), "Entrepreneurship in golden years - creative opportunity or not?", China-USA Business Review, Vol. 12 No. 1, pp. 52-66.

Henry, C., Foss, L. and Ahl, H. (2016), "Gender and entrepreneurship research: a review of methodological approaches”, International Small Business Journal: Researching Entrepreneurship, Vol. 34 No. 3, pp. 217-241, doi: 10.1177/0266242614549779.

Ilmarinen, J. (2006), Towards a Longer Worklife - Ageing and the Quality of Worklife in the European Union, Finnish Institute of Occupational Health, Helsinki.

ILO and OECD (2019), "New job opportunities in an ageing society", Paper Prepared for the 1st Meeting of the G20 Employment Working Group, Tokyo, Japan, 25-27 February, available at: https://www.oecd.org/g20/summits/osaka/ILO-OECD-G20-Paper-1-3-New-job-opportunities-inan-ageing-society.pdf (accessed 29 June 2019).

Isele, E. and Rogoff, E.G. (2014), "Senior entrepreneurship: the new normal", Public Policy and Aging Report, Vol. 24 No. 4, pp. 141-147, Oxford University Press on behalf of The Gerontological Society of America.

Järnefelt, N. (2011), Ikääntyneiden Yrittäjyys on Lisääntynyt. [Entrepreneurship of Older People Has Increased], Hyvinvointikatsaus 4/2011, available at: https://www.stat.fi/artikkelit/2011/art_ 2011-12-12_001.html? $=0$ (accessed 7 October 2021).

Jamil, N., Rosie, C., Nasah, J. and Hassan, Z. (2014), "The feasibility of entrepreneurship after retirement", Malaysian Journal of Business and Economics, Vol. 1 No. 1, pp. 19-33.

Jayo, B., González, A. and Conzett, C. (2010), "Overview of the microcredit sector in the European union”, European Microfinance Network, EMN Working Paper No. 6, June 2010.

Katz, S. and Calasanti, T. (2014), "Critical perspectives on successful aging: does it "appeal more than it illuminates", The Gerontologist. Special Issue: Successful Aging.

Kauko-Valli, S. (2008), "Subjective well-being as an individually constructed phenomenon", Studies in Business and Economics, University of Jyväskylä, Jyväskylä, Vol. 63, available at: https://jyx.jyu. fi/bitstream/handle/123456789/41964/978-951-39-5290-7_2008.pdf?sequence=1\&isAllowed=y (accessed 28 December 2019).

Kautonen, T. (2008), "Understanding the older entrepreneur: comparing third age and prime age entrepreneurs in Finland", International Journal of Business Science and Applied Management, Vol. 3 No. 3, pp. 3-13.

Kautonen, T. (2013), "Senior entrepreneurship", A Background Paper for the OECD Centre for Entrepreneurship, SMEs and Local Development, OECD, available at: https://www.dcu.ie/sites/ default/files/agefriendly/senior_bp_final.pdf (accessed 21 May 2019).

Kautonen, T., Down, S. and Minniti, M. (2014), "Ageing and entrepreneurial preferences", Small Business Economics, Vol. 42 No. 3, pp. 579-594, doi: 10.1007/s11187-013-9489-5.

Kautonen, T., Hatak, I., Kibler, E. and Wainwright, T. (2015), "Emergence of entrepreneurial behavior: the role of age-based self-image", Journal of Economic Psychology, Vol. 50, pp. 41-51, doi: 10. 1016/j.joep.2015.07.004.

Khan, H. (2013), Five Hours a Day Systemic Innovation for an Ageing Population, Nesta, available at: https://media.nesta.org.uk/documents/five_hours_a_day_jan13.pdf (accessed 3 March 2021).

Kibler, E., Wainwright, T., Kautonen, T. and Blackburn, R.A. (2012), (Work)life after Work?: Older Entrepreneurship in London - Motivations and Barriers, Small Business Research Centre, Kingston University London, available at: http://citeseerx.ist.psu.edu/viewdoc/download? doi=10.1.1.888.6754\&rep=rep1\&type $=$ pdf $($ accessed 3 March 2021). 
Kohli, M. (1991), "Ikääntyneiden työmarkkinat ja aktiivisuusmallit ikääntyvässä yhteiskunnassa. [Senior citizens' labour market and activity models in ageing society]", Gerontologia, Vol. 5 No. 3, pp. 209-222.

Kooij, D., de Lange, A., Jansen, P. and Dikkers, J. (2008), "Older workers' motivation to continue to work: five meanings of age: a conceptual review", Journal of Managerial Psychology, Vol. 23 No. 4, pp. 364-394.

Kovalainen, A. (1992), "Uusia mahdollisuuksia naisten yritystoiminnalle [New chances for female entrepreneurship]”, in Jahnukainen, I. (Ed.), Uudistuva Pienyritys, [Renewal of Family Business], Weilin + Göös, Jyväskylä, pp. 65-77.

Kovalainen, A. (1999), "Uusia mahdollisuuksia naisten yritystoiminnalle [New chances for female entrepreneurship]", in Lehtonen, P. (Ed.), Straginen Yrittäjyys. [Strategic Entrepreneurship], Multiprint, Helsinki, pp. 24-47.

Kyrö, P., Pohjola, K., Torikka, J. and Tyrväinen, P. (2002), "The Finnish country report - statistics of woman entrepreneurship", in Kyrö, P. (Ed.), Woman Entrepreneurship in the Nordic Countries. Vol. II. Country Reports: Denmark, Finland, Iceland, Norway, Sweden, University of Jyväskylä, Jyväskylä, Reports from the School of Business and Economics, No. 27/2002, pp. 31-37.

Kyrö, P., Moisala, A., Nyrhinen, S. and Levikari, N. (2012), "Kohti joustavia senioriyrittäjyyden polkuja. [Towards flexible paths of senior entrepreneurship]", Raportti Oma Projekti Seniorina Yrittäjäksi -tutkimushankkeesta 2012, Pienyrityskeskus. Aalto-Yliopisto, available at: http://epub.lib.aalto.fi/pdf/hseother/Aalto_Report_KT_2012_001.pdf (accessed 21 May 2019).

Lechner, C. and Dowling, M. (2003), "Firm networks: external relationships as sources for the growth and competitiveness of entrepreneurial firms", Entrepreneurship and Regional Development, Vol. 15 No. 1, pp. 1-26.

Luck, F., Kraus, S. and Bouncken, R.B. (2014), "Senior entrepreneurship: definitions and underlying theories", International Journal of Business Research, Vol. 14 No. 3, pp. 209-215.

Mainieiro, L.A. and Sullivan, S.E. (2005), "Kaleidoscope careers: an alternate explanation for the 'opt-out' revolution”, Academy of Management Executive, Vol. 19 No. 1, pp. 106-123.

Marcketti, S.B., Niehm, L.S. and Fuloria, R. (2006), "An exploratory study of lifestyle entrepreneurship and its relationship to life quality", Family and Consumer Sciences Research Journal, Vol. 34 No. 3, pp. 241-259.

Maritz, A. (2015), "Senior entrepreneurship in Australia: an exploratory approach", The International Journal of Organizational Innovation, Vol. 7 No. 3, pp. 6-23.

Martin, L. and Omrani, N. (2019), "Understanding senior entrepreneur behavior", Journal of Enterprising Culture, Vol. 27 No. 3, (September 2019), pp. 259-282, doi: 10.1142/ S0218495819500109.

Masurel, E. and Snellenberg, R. (2017), "Does the lifestyle entrepreneur exist? An analysis of lifestyle entrepreneurs compared with other entrepreneurs on the basis of the development of entrepreneurial competences", Research Memorandum 2017-1, School of Business and Economics, Vrije Universiteit Amsterdam, available at: https://research.vu.nl/ws/portalfiles/ portal/40835458/2017_1_2.pdf (accessed 12 March 2021).

McAlpine, L. (2016), "Why might you use narrative methodology? A story about narrative", Eesti Haridusteaduste Ajakiri, Vol. 4 No. 1, pp. 32-57, doi: 10.12697/eha.2016.4.1.02b.

McKay, R. (2001), "Women entrepreneurs: moving beyond family and flexibility", International Journal of Entrepreneurial Behaviour and Research, Vol. 7, pp. 148-165.

Merriam, S.B. and Kee, Y. (2013), "Promoting community wellbeing: the case for lifelong learning for older adults", American Association for Adult and Continuing Education, Adult Education Quarterly 201X, Vol. XX No. X, pp. 1-17.

\section{Women's entrepreneurship at an older age}


QROM

17,2

Ministry of Employment and Economy [MEE] (2012), Yrittäjyyskatsaus 2012 [Business Review 2012], MEE Publications, Employment and Economy 46/2012, available at: https:/tem.fi/documents/ 1410877/3342347/Yritt\%C3\%A4jyyskatsaus+2012+08112012.pdf (accessed 8 March 2021).

Mishler, E.O. (1990), "Validation in inquiry-guided research: the role of exemplars in narrative studies", Harvard Educational Review, Vol. 60, p. 41.

Moore, I. (2020), Female Entrepreneurship in Later Life: The Next Chapter, available at: https:// olderwomeninbusiness.com/wp-content/uploads/2020/03/Female-Entrepreneurship-ReportMarch20.pdf (accessed 4 February 2021).

Morris, M. (1998), Entrepreneurial Intensity Sustainable Advantages for Individuals, Organizations, and Societies, Quorum Books, CTWestport.

Nivalainen, S. and Tenhunen, S. (2019), Yrittäjien Eläkeaikeet - Työolojen Ja Eläketurvan Merkitys. Elaketurvakeskuksen Tutkimuksia 1/2019. [Entrepreneurs' Retirement Intentions - the Effect of Working Conditions and Pension Insurance], available at: http://urn.fi/URN:ISBN:978-951-691000-3 (accessed 7 October 2021).

Noble, B. (1986), “A sense of self”, Venture, July, pp. 34-36.

Nykänen, S., Saukkonen, S. and Vuorinen, R. (2012), “Transformations in lifelong guidance provision”, in Tynjälä, P., Stenström, M.-L. and Saarnivaara, M. (Eds), Transitions and Transformations in Learning and Education, Springer, Basel, pp. 187-202.

OECD (2013), Trends Shaping Education Spotlights. Ageing Societies, OECD Publishing, available at: http://www.oecd.org/education/ceri/Ageing_Societies_Spotlight.pdf (accessed 30 June 2019).

OECD (2017), Entrepreneurship at a Glance 2017, OECD Publishing, Paris. doi: 10.1787/entrepreneur_ aag-2017-en.

OECD/European Union (2017), The Missing Entrepreneurs 2017: Policies for Inclusive Entrepreneurship, OECD Publishing, Paris. doi: 10.1787/9789264283602-en.

Orhan, M. and Scott, D. (2001), "Why women enter into entrepreneurship: an explanatory model", Women in Management Review, Vol. 16 No. 5, pp. 232-247, doi: 10.1108/09649420110395719.

O'Neil, D.A., Hopkins, M.M. and Bilimoria, D. (2008), "Women's careers at the start of the 21st century: patterns and paradoxes", Journal of Business Ethics, Vol. 80, pp. 727-743.

Pääkkönen, H. and Hanif, R. (2011), Ajankäytön Muutokset 2000-luvulla. [Changes in Time Use in the Twenty-First Century], Statistics Finland, available at: https://www.tilastokeskus.fi/tup/ julkaisut/tiedostot/isbn_978-952-244-331-1.pdf (accessed 20 October 2021).

Pilkova, A., Holienka, M. and Rehaka, J. (2014), "Senior entrepreneurship in the perspective of European entrepreneurial environment", Procedia Economics and Finance, Vol. 12 No. 2014, pp. 523-532.

Pöllänen, P. (2002), "Hoivayrittäjyyden aika naisen elämänkulussa. [Caring entrepreneurship time in woman's life time]", Yhteiskuntapolitiikka, Vol. 67 No. 6, pp. 558-563.

Raivio, H. and Karjalainen, J. (2013), "Osallisuus ei ole keino tai väline, palvelut ovat! Osallisuuden rakentuminen 2010-luvun tavoite- ja toimintaohjelmissa. [Participating is neither way nor means, services are! Establishing participation of goal and activity programmes in 2010s]", in Era, T. (Ed.), Osallisuus - Oikeutta Vai Pakkoa? [Participation - Justice or Coercion?], Jyväskylän ammattikorkeakoulun julkaisuja, Jyväskylä, Vol. 156, available at: URN:ISBN:978-951-830-280-6.

Reijonen, H. and Komppula, R. (2004), Craft Entrepreneur's Growth-Motivation - a Case Study of Female Entrepreneurs in North Karelia, Discussion Papers No. 18, University of Joensuu Department of Business and Economics (Marketing), available at: https://erepo.uef.fi/bitstream/ handle/123456789/8605/urn_isbn_952-458-515-4.pdf?sequence=1 (accessed 12 March 2021).

Reynolds, P.D., Bygrave, W.D., Autio, E., Cox, L.W. and Hay, M. (2002), Global Entrepreneurship Monitor, 2002 Executive Report, Babson College London Business School. Ewing Marion Kauffman Foundation.

Richardson, C. (1996), "Snakes and ladders? The differing career patterns of male \& female accountants_, Women in Management Review, Vol. 11 No. 4, pp. 13-19. 
Robb, A.M. and Coleman, S. (2010), "Financing strategies of new technology-based firms: a comparison of women-and men-owned firms", Journal of Technology Management and Innovation, Vol. 5 No. 2, pp. 30-35.

Rowe, J.W. (1997), “The new gerontology”, Science (New York, N.Y.), Vol. 278, p. 367, doi: 10.1126/ science.278.5337.367.

Rowe, J.W. and Kahn, R.L. (1997), "Successful aging”, The Gerontologist, Vol. 37, pp. 433-441.

Russell, J.E.A. (2001), "Vocational psychology: an analysis and directions for the future", Journal of Vocational Behavior, University Maryland, Vol. 59, pp. 226-234.

Schøtt, T., Rogoff, E., Errington, M. and Kew, P. (2017), GEM Special Report on Senior Entrepreneurship 2017, Global Entrepreneurship Research Association, available at: https:// gemconsortium.org/report/gem-2016-2017-report-on-senior-entrepreneurship (accessed 12 March 2021).

Seligman, M.E.P. (2011), Flourish: A Visionary New Understanding of Happiness and Well-Being, Free Press, New York, NY.

Seligman, M. (2018), "PERMA and the building blocks of well-being", The Journal of Positive Psychology, Vol. 13 No. 4, pp. 333-335, doi: 10.1080/17439760.2018.1437466.

Seymour, N. (2002), "Starting up after 50", CELCEE Digest, available at: https:/files.eric.ed.gov/ fulltext/ED476585.pdf (accessed 12 March 2021).

Singh, G. and DeNoble, A. (2003), "Early retirees as the next generation of entrepreneurs", Entrepreneurship, Theory and Practice, Vol. 27 No. 3, pp. 207-226, doi: 10.1111/1540-8520.t01$1-00001$.

Stowe, J.D. and Cooney, T.M. (2015), "Examining Rowe and Kahn's concept of successful aging: importance of taking a life course perspective”, Gerontologist, Vol. 55 No. 1, pp. 43-50.

Sullivan, S.E. and Baruch, Y. (2009), "Advances in career theory and research: a critical review and agenda for future exploration”, Journal of Management, Vol. 35 No. 6, pp. 1542-1571, doi: 10. 1177/0149206309350082.

Suomalainen, S., Stenholm, P., Kovalainen, A., Heinonen, J. and Pukkinen, T. (2015), Global Entrepreneurship Monitor, Finnish 2015 Report, Turku School of Economics, University of Turku TSE ENTRE, series a research reports A 1/2016, available at: https://www. gemconsortium.org/economy-profiles/finland (accessed 12 March 2021).

Suomen yrittäjät [Association of Finnish Entrepreneurs] (2019), Yksinyrittäjäkysely 2019. [Solo Entrepreneur Survey 2019], available at: https:/www.yrittajat.fi/sites/default/files/ yksinyrittajakysely_2019_0.pdf (accessed 20 October 2021).

Super, D.E. (1957), The Psychology of Careers. An Introduction to Vocational Development, Harper \& Brothers, New York.

Super, D.E. (1990), “A life-span, life-space approach to career development”, in Brown, D. and Brooks, L. (Eds), Career Choice and Development: Applying Contemporary Theories to Practice, 2nd ed., Jossey-Bass Publishers, San Francisco, pp. 197-261.

Sutela, H. and Pärnänen, A. (2018), YRITTÄJ̈̈T SUOMESSA 2017. [Entrepreneurs in Finland], Statistics Finland, Helsinki.

Takanen-Körperich, P. (2008), "Sama koulutus - eri urat. [Same education - different careers", in Jyväskylä Studies in Business and Economics, University of Jyväskylä, Vol. 66, available at: http://urn.fi/URN:ISBN:978-951-39-3261-9.

Terjesen, S. (2005), "Senior Women managers' transition to entrepreneurship: leveraging embedded career capital", Career Development International, Vol. 10 No. 3, pp. 246-259.

Tervo, H. and Haapanen, M. (2017), "Opportunity- and necessity-driven self-employment among older people in Finland", in Aaltio, I., Mills, A.J. and Helms Mills, J. (Eds), Ageing, Organisations and Management. Constructive Discourses and Critical Perspectives, Palgrave Macmillan, Springer 
QROM

17,2

Nature, Cham, pp. 255-276, available at: https://1lib.sk/book/3376004/d5af67 (accessed 25 February 2022).

Thébaud, S. (2015), "Business as plan b: institutional foundations of gender inequity in entrepreneurship across 24 industrialized countries", Administrative Science Quarterly, Vol. 60 No. 494, pp. 671-711.

Tomlinson, F. and Colgan, F. (2014), "Negotiating the self between past and present: narratives of older women moving towards self-employment", Organization Studies, Vol. 35 No. 11, pp. $1655-1675$.

Tuomi-Nikula, O. (1989), Saksansuomalaiset. Tutkimus Syntyperäisten Suomalaisten Akkulturaatiosta Saksan Liittotasavallassa Ja Länsi-Berliinissä,[The Finnish Nationals in Germany. Research on the Acculturation of the Finnish Nationals in German Republic and West-Berlin], Suomalaisen kirjallisuuden seura, Helsinki.

Uotinen, V., Rantanen, T. and Suutama, T. (2005), "Perceived age as predictor of old age mortality: a 13-year prospective study”, Age and Ageing, Vol. 34 No. 2005, pp. 368-372.

Vaara, R. (2000), "Työstä luopuminen, ikääntymisen todellisuudet ja oppimisen uudet mahdollisuudet. [Retiring, reality of ageing and new chances of learning]", in Sallila, P. (Ed.), Oppiminen ja Ikääntyminen. [Learning and Ageing], Aikuiskasvatuksen, vuosikirja, Vol. 41, pp. 116-141.

Vainio-Korhonen, K. (2002), Ruokaa, Vaatteita, Hoivaa. Naiset Ja Yrittäjyys Paikallisena Ja Yleisenä Ilmiönä 1700-luvulta Nykypäivään. [Food, Clothes, Caring. Women and Entrepreneurship as Local and General Phenomenon from 1700's until today.], Suomalaisen kirjallisuuden seura, Helsinki.

van der Zwan, P., Thurik, R., Hessels, J. and Verheul, I. (2016), "Factors influencing the entrepreneurial engagement of opportunity and necessity entrepreneurs", Eurasian Business Review, Vol. 6, pp. 273-295, doi: 10.1007/s40821-016-0065-1.

Vardhan, J., Bohra, S., Abdullah, A., Thennarasu, K. and Jagannathan, S.K. (2020), "Push or pull motivation? A study of migrant women entrepreneurs in UAE”, International Journal of Family Business and Regional Development, Vol. I No. I, 2020, pp. 8-24, doi: 10.1504/IJFBRD.2020. 111443.

Vuorinen, R. and Watts, A.G. (2010), Lifelong Guidance Policies: Work in Progress, A report on the work of the European Lifelong Guidance Policy Network 2008-10, European Lifelong Guidance Policy Network (ELGPN), available at: http://www.elgpn.eu/publications/browse-by-language/ english/european-lifelong-guidance-policies-work-in-progress-a-report-on-the-work-of-theeuropean-lifelong-guidance-policy-network-2009201310/ (accessed 12 March 2021).

Wang, M. and Shi, J. (2014), "Psychological research on retirement", Annual Review of Psychology, Vol. 65, pp. 209-233.

Way, M.M. (2015), "Reservation wage", Wiley Encyclopedia of ManagementManagerial Economics, Vol. 8, 21 January, doi: 10.1002/9781118785317.weom080091.

Weber, P. and Schaper, M. (2003), "Understanding the grey entrepreneur: a review of the literature", 16th Annual Conference of Small Enterprise Association of Australia and New Zealand, 28 September -1 October.

Welsh, D.H.B. and Dragusin, M. (2006), "Women-entrepreneurs: a dynamic force of the small business sector", Amfiteatru Economic, Vol. 20, pp. 60-68.

Welter, F. (2004), "The environment for female entrepreneurship in Germany", Journal of Small Business and Enterprise Development, Vol. 11 No. 2, pp. 212-221 2004).

White, H. (1989), "The rhetoric of interpretation", in Hernadi, P. (Ed.), The Rhetoric of Interpretation and Interpretation of Rhetoric, DOKE University Press, Durham, NC.

Withnall, A. (2012), "Lifelong or longlife? Learning in the later years", in Aspin, D.N., Chapman, J., Evans, K. and Bagnall, R. (Eds), Second International Handbook of Lifelong Learning, Part 2, Springer, New York, NY, pp. 649-664. 
Yaniv, E. and Brock, D. (2012), "Reluctant entrepreneurs: why they do it and how they do it", Ivey Business Journal, November/December 2012, available at: https://iveybusinessjournal.com/ publication/reluctant-entrepreneurs-why-they-do-it-and-how-they-do-it/ (accessed 4 February 2021).

Women's entrepreneurship at an older age

\section{Corresponding author}

Tarja Römer-Paakkanen can be contacted at: tarja.romer-paakkanen@haaga-helia.fi 